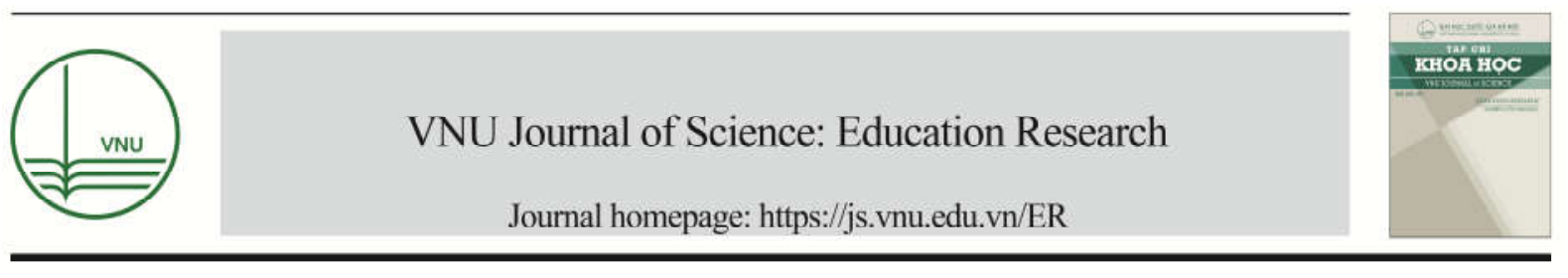

\title{
Skill Gap from Employers' Evaluation: A case of VNU Graduates
}

\author{
Mai Thi Quynh Lan* \\ VNU Institute of Education Quality Assurance, \\ 144 Xuan Thuy, Cau Giay, Hanoi, Vietnam \\ Received 22 May 2018 \\ Revised 28 May 2018; Accepted 29 May 2018
}

\begin{abstract}
With globalization, the university-work transition has become increasingly challenging for graduates and employers. In the new context, the mission of university has shifted, and knowledge is no longer considered as singular [1]. The traditional role of universities in producing knowledge has changed to give more focus on the demands of society. The "codified knowledge" acquired from didactic teaching in universities can be at odds with the often "informal and tacit" knowledge required in the workplace. The development of information technology makes the nature of work changing very fast; graduates need to achieve attributes that help them not only do the work corresponding with their disciplines, but be able to learn new skills and new knowledge. This paper presents the preliminary results of a questionnaire survey among 25 employers of VNU School of Law's graduates to explore employers' evaluation of the employability of graduates from Vietnam National University Hanoi. Applying theories of graduate attributes [2], employability [3] and graduate transferable skills [4, 5], the survey explores the gap between university study and the requirements at the work market of graduates. This paper argues that there is considerable distance between university knowledge and skills and the nature of the work. Graduates lack transferable skills, those that allow them to acquire the necessary skills, to satisfy the requirements of the morden workplace, to transfer abstract cognitive skills. These skills are needed before the graduates enter the work market as the employers expect them to practice these skills competently at work. Although these skills can be generated through work, the employers do emphasise their importance for univesrity graduates. Therefore the university teaching and learning process should be reviewed and revised (if necessary) to develop these transferable skills during the time at the university.
\end{abstract}

Keywords: Graduate attributes, employability, Vietnam, general competences, transferable skills.

\section{The requirement of globalised world?}

Globalisation is a phenomenon that has been occurring in the world since ancient times

\footnotetext{
* Tel.: 84-1236721598.

Email: lanmtq@vnu.edu.vn

https://doi.org/10.25073/2588-1159/vnuer.4137
}

and has been present in all aspects of human society. Amartya Sen [6], the Economic Nobel Laureate, claims that "over thousands of years, globalisation has contributed to the progress of the world through travel, trade, migration, spread of cultural influences, and dissemination of knowledge and understanding (including that 
of science and technology)". Globalisation is defined as the diffusion of ideas, practices and technologies, and intensified worldwide social relations, which now link once disconnected, distant localities [7] (pp. 17-19). Marginson and van der Wende [8] clarify that globalisation widens, deepens and speeds up worldwide interconnectedness in terms of geo-spatial relations. From their perspective, globalisation enhances growing inter-dependence and convergence among nations throughout the world or within a region [8]. Globalisation also facilitates and forces several global flows which have visible effects, for example: the flows of people (students, administrators, academic faculty); flows of media and messages, information and knowledge; flows of norms, ideas and policies; and flows of technologies, financial capital and economic resources [9], [10]. However, globalisation also facilitates flows with less visible effects, such as the diversification of languages, cultures, pedagogies and scholarship, and competitive differentiation [10] (p. 304).

\section{Graduate attributes}

Throughout the world, there is increasing interest in measuring the "learning outcomes" of university graduates [11] to clarify the nature of the education they offer to their students. Graduate attributes are understood as the qualities, skills and understanding that a university community agrees its students should develop during their time with the institution [2]. However, there is no consensus on a definition of graduate attributes, e.g. [5]. In a mixed methods research conducted by Bennett, Dunne and Carré [1], the model of generic skillsare conceptualised to include the main skills associated with "management of information", particularly communication, and skills of "management of self" and "management of task" according to the demands of the jobs. Bennett et al.'s [1] research provides evidence that the skills that individual graduates developed are constrained and enabled by work circumstances. Particular circumstances influence the way graduates use their knowledge, from directly applying specific skills to strategically thinking about application of more abstract knowledge. Bennett et al.'s [1] (p. 16) refer this to "transfer of learning" as that which "occurs when a person applies knowledge or skills acquired in one context in a new context".

Bennett et al., [1] classify attributes into near transfer and far transfer attributes, depending on the context of transfer. Near transfer attributes involve "fast automatization" for "skills that are identical in different task situations"; they are the attributes that enable graduates to transfer knowledge and skills to contexts similar to educational contexts (p. 17). Alternatively, far transfer attributes are those that infuse and enable all scholarly learning and knowledge; transcend disciplinary boundaries; enable students to reshape and transform knowledge to meet new challenges in contexts far from the original discipline; vary over task situations; and require more conditional, and deeper, disciplinary content knowledge (p. 17).

Similarly, Barrie [2] posits that academics" understandings of graduates attributes were categorised into a four level framework. These four levels, arranged according to their increasing complexities are: 1 - precursory; 2 - complementary; 3 - translational; 4 enabling attributes [2] (pp. 223-224). The higher levels are understood to encompass attributes from the lower levels.

Elements of both Bennett et al.'s [1] and Barrie's [2] schemas can be seen also in Eraut's [12] classification of graduate attributes. Similar to the classification of Bennett et al. [1] that categorises graduate attributes according to the similarity of the contexts of application (near and far; or low road and high road), Eraut [12] classifies the knowledge transfer process into five levels, depending on the context where it is applied, differentiating between the levels of transfer, as either being easy and short in a similar situation, to being long and challenging 
in quite an unfamiliar and complex context. The latter involves: (i) the extraction of potentially relevant knowledge from the context(s) of its acquisition and previous use; (ii) understanding the new situation, a process that often depends on informal social learning; (iii) recognising what knowledge and skills are relevant; (iv) transforming them to fit the new situation; (v) integrating them with other knowledge and skills in order to think/act/communicate in the new situation [12] (p. 212).

In general, among models of graduate attributes, both Eraut's categorisation and Barrie's [2] classification link graduates attributes with the processes of acquiring discipline knowledge. In addition, Eraut conceptualises the processes by which graduates use the knowledge in work contexts, post graduation. Notably, most of the existing research on graduate attributes targets academies and/or employers, e.g. $[2,5,13]$. As a result, the listed graduate attributes are the expectations of the academics and employers towards the graduates.

\section{Graduate transferable skills}

According to Harvey et al., [14] cited in [15], most employers are looking for graduates who are proactive, can use higher level skills including "analysis, critique, synthesis and multi layered communication to facilitate innovative teamwork in catalyzing the transformation of their organization". In Roger Bennett's[4] analyse of the content of 1000 job advertisements and empirical study on employers' demands for personal transferable skills in graduates, Bennett contents that transferable skills are skills that are needed in any job and which enable people to participate in a flexible and adaptable workforce. Bennett summarises transferable skills to include personal skills such as the ability to work well with others, the ability to organise, selfmotivation, "a basic capability to use information technology" plus, communication skills, initiative, creativity, the capacity to solve problems, and leadership. Bennett reasons that transferable skills are important because they permit a freshly appointed graduate to make an immediate contribution to a business, especially within a smaller firm. "Transferable skills" - is a term in common parlance within education. The implication in the term is that skills developed within one situation (education) are also useful when transferred into another situation (employment) [16]. Transferable skills are those that are not specific to the subject you are studying, but which are much valued by employers: such as effective communication and teamwork [17].

Similarly, Lowden, Hall, Elliot, Lewin [18] conduct anempirical study in Glasgow - UK on employers" perceptions of the employability skills of new graduates. Some graduates and their employers explicitly explain that students' wider skills and attributes, including teamworking, communication, leadership, critical thinking and problem solving should get more focus. Their research findings respond well to the literature body on employability skills. They categorise these skills into core skills; key skills; common skills; transferable skills; essential skills; functional skills; skills for life; generic skills and enterprise skills. Most of the listed employability skills in Lowden et al.'s research are covered in the list made by Bennett [4].

Haigh \& Kilmartin [17] agree that transferable skills include: Problem solving (Analysis, Lateral thinking, Setting questions, Identifying strategies, Evaluating success); Communication (Reading/listening, Choice of styles, Coherent argument. Analysis, Synthesis, Self evaluation, Peer evaluation, Author evaluation); Learning skill (Independence, Co-operation, Ranges of strategies); Self management (Clarify values, Set goals, Manage time, Assess self); Information skills (Literature research, Information retrieval, Information handling, Referencing); Teamwork (Taking responsibility, Taking initiative, Negotiation, Team evaluation). Similarly, Fallows and 
Steven [16] state that transferable skills are Retrieval and handling of information; Communication and presentation; Planning and problem solving; Social development and interaction.

However, Bennett [1] posit that there is no consensus in the academic literature regarding which particular transferable personal skills are most and least important. Typically, surveys have asked employers either to list or rank the skills they believed to be essential, or have examined the in-house literatures of recruiting companies.

The general list of transferable skills can be broadly understood as qualities, characteristics, skills and knowledge constitute employability both in general, and specifically for graduates. Transferable skills might include:

+ Personal skills to work well with others (or team work skills)

+ The ability to organise,

+ Self-motivation,

+ "A basic capability to use information technology";

+ Communication skills,

+ Initiative,

+ Creativity,

+ The capacity to solve problems,

+ Critical thinking;

+ Leadership.

Transferable skills are not separated from higher education. In Barrie's [2] four level framework of graduate attributes according to the complexitiveness, transferable skills are placed in the two high levels of skills which are closely linked with higher education:

- In level one, the precursory attributes are the learning outcomes that should pre-exist in university students, hence, understood as essential foundation to university study but not expected to be taught there and essentially ignored in thinking about learning outcomes at university level.

- In level two, the complementary attributes are useful additional skills that complement or round out graduates' discipline knowledge. These attributes are acquired as the result of a university education, but are separate and secondary to the learning of disciplinary knowledge. They are functional, atomistic, personal skills that are quite discrete from other university learning outcomes.

- In level three, the translation conception includes the generic attributes as abilities that let graduates make use of, or apply, disciplinary knowledge, thus potentially changing and transforming disciplinary knowledge through its application. Included in this level are clusters of linked personal attributes, cognitive abilities and skills of application, which are the learning outcomes that graduates possess in partnership with discipline knowledge.

- In level four are the enabling generic attributes that are integrated in the learning outcomes. These are abilities that infuse and enable all scholarly learning and knowledge. They are interwoven abilities and aptitudes for learning. These attributes are of significant importance as they provide the building blocks for discipline knowledge but are more long lasting and important than the discipline knowledge they support. Once developed, these graduate attributes are perceived to provide a reusable framework that enables students/graduates to acquire and shape new knowledge as required - even in the context of other disciplines. These generic attributes are seen as transcending disciplinary boundaries even though they are initially developed within disciplinary contexts [2] (pp. 229-230).

\section{Why are transferable skills important in globalised world?}

Reported literature suggests there is no one best way to examine the set of skills that makes graduate more employable. Employers' perceptions play a key role in the definition of the required skills for graduates [19]. A blend of understanding, skilful practices, efficacy beliefs (or legitimate self-confidence) and reflectiveness (or metacognition) [20]. Capable people have confidence in their ability to take 
effective and appropriate action, explain what they are seeking to achieve, live and work effectively with others, and continue to learn from their experiences, both as individuals and in association with others, in a diverse and changing society [21].

The literature on employability has suggested that it depends upon a synergic blend of personal qualities, skills of various kinds (of which "key skills" are a subset) and disciplinary understanding [3]. These authors develop the USEM model from the concept of "capability" combinedwith the interpretation of the literature with insights from cognitive and social psychology, including Understanding; Skills (subject-specific and generic); Efficacy beliefs (and self-theories generally); and Metacognition (including reflection).

In the context of social change and massification of higher education, employers are looking for graduates with generic attributes in addition to degree or program knowledge; employers highly value the attributes which assist the graduates to adapt to the workplace, to be flexible in moving between different jobs, and to move "one's repertoire of knowledge" onward [22]. Company requires workers with flexible skills, trainability, persuasive skills and teamwork skills [23]; proactive, can use higher level skills including "analysis, critique, synthesis and multi layered communication to facilitate innovative teamwork in catalyzing the transformation of their organization" [14]; adapt to the workplace, flexible in moving between different jobs, move "one's repertoire of knowledge" onward [22].

These desirable attributes are often independent of the degree subject, and consist of interactive attributes, including communication skills, interpersonal skills and team working, as well as personal attributes, including intellect and problem solving, analytic, critical and reflective ability, willingness to learn and continue learning, flexibility and adaptability, risk-taking and selfskills (Harvey in [22]).
Job skills are changing so rapidly, with new types of jobs being created, employers find that formal learning does not keep pace with the changing needs of the workforce; therefore,they are not looking for perfect fit employees, nor expecting higher education to produce graduates who can meet all work requirements, they look for learning ability [23]. In other way, organizations are constantly changing but higher education can not react continually to the changing needs; as a result employers focus on the learning skill of the employees [24]. The company requires workers to have flexible skills, trainability, persuasive skills and teamwork skills, not because the company lacks confidence in graduates but because the company recognizes that graduates have the ability to develop specific skills, processes, and systems of values [23].

Suleman [19] (p.173) questions why wide agreement was only found for interpersonal skills, communication and team-work skills, which are relational skills? The author reasons that inreality these are included in almost all catalogues and more importantly because they can be observed directly. Employers can therefore easily observe and assess relational skills. However, Suleman argues that other hard-to-observe skills are also required. Employers have always been concerned about the unobservable characteristics of job candidates. They often use third-party certification to ascertain whether a job seeker is suitable for the position and consequently use education as a screening device to distinguish the more able from the less able applicants without incurring additional costs [19](p.173).

\section{Vietnam context}

Economy renovation (Doi Moi policy) was introduced by the Vietnamese government in 1986 to allow the economy to transform from a planned to a market-oriented one. The demand for a workforce to meet the requirements of those changes in the society is placed upon the 
Universities. Nonetheless, it was not until 1993 that the first non-public higher education institution regulation was issued. Since then, the number of universities has risen remarkably, and ultimately doubled after 10 years. However, economic reform and the massification of universities means that graduates are no longer provided jobs after graduation, but rather they have to compete in an open job market. The traditional view in Vietnam that university education is training for life-long work within one profession is no longer appropriate for all graduates, and thus, the traditional professionfocused training structure at universities lags behind the changing job market.

Like elsewhere in the world, e.g. [22], employers in Vietnam desire graduate attributes that match the contemporary workplace, such as "learning, communication, information processing, problem solving, and interpersonal skills" [25]. These authors argue that while universities focus on problem solving skills such as "decision-making, learning, and information processing" employers would also like them to focus on the development of "interpersonal skills" such as negotiation skills, coaching skills and conflict management skills.

A survey conducted by Nguyen Thi Thanh Hong [26], among a sample of 400 education students, demonstrates that the learning methods used by these students at university were frequently characterized by "notetaking, combined with reading textbooks and reference material", "learning by memorising the lecture notes given in class", and "learning according to what has been set out by the course outline and syllabus". There is increasing concern that the limited scope, content and approaches to learning that students obtain from such university courses are inadequate to the demands of both education and other professional practices $[25,26]$. Employers' most concern for soft skills or attitudes and generic skills; these demands seem consistent, even when there are structural changes, and labour demand fluctuates [27].
Mai's [28] research among young graduates working at the intercultural environment at INGOs confirms that in the globalisation era, young graduates lacks cultural competence, which is a necessary employability skill for successful engagement in today's world of work. Nonetheless, cultural competence was not edequately developed at the universities. Mai's interviews with young graduates working at INGOs uncover contradictions between their unviersity study and work requirements at INGOs. Most of them experienced traditional teacher-focus teaching approach at their universities. However, INGOs workplace requires graduates to be continuous learners, to have critical mindset, to possess effective negotiation, communication and interpersonal skills, and particularly to be culturally competent. Young graduates' stories exposed their hardship at the beginning of their work at INGOs. The typical traditional teaching and learning aproach at university clear influenced their work style after graduation. Despite of their good command of English language at universities, most of young informants (both girl and boy) had difficulties in interpreting and translating English at their first jobs. Most of them started their careers in intern positions or positions such as interpreters or project assistants. Translation in the context of INGOs is not a simple transfer of meaning between people who do not speak the same language. Young graduates need to mediate between international experts and local people whose cultural dispositions, practices and customs are not the same [28].

It was difficult for the person in the middle to understand the differences in the system of values of other cultures. Those dealing with different ethnic groups had even more challenging tasks. They had to understand the two different cultures, at the same time had to ensure that they enable both sides to work together to come to a new understanding. It is noticeable that the cultural mediation role was not an explicitly stated task of any young graduate but the intercultural organisational 
context, flexible working conditions particularly fosters the development of cultural mediation capacity [28].

\section{The Research}

This research uses questionnaire survey method to explore employers' evaluation of the employability of graduates from Vietnam National University Hanoi, started from January 2018. The purpose of the survey is to explore the gap between university study and the requirements at the work market. This research method follows what Tuning Academy in Spain, funded by the European Council, had conducted through a series of research projects to identify competences that the work market requires from employees. In their project for South East Asia region, they consulted academia and management personel of universities in South East Asia and some of Universities in Europe to develop the list of 13 general competences. Based on the agreed competencies they are developing meta profiles for programs including Civil Engineering, Teacher training, and Medicine.

Using this list of agreed general competences, the research team at VNU Institute for Education Quality Assurance conducted a questionnaire survey among the employers of graduates from VNU School of Law. This is a part of an ongoing survey among employers of graduates from 7 member units of VNU. VNU School of Law invited employers of their graduates to a seminar to discuss with the academics how to strengthen the linkage between two sides to make the Law program more relevant to reality.

Fifty questionnaires were distributed to the participants, of which twenty five were returned. The respondents include 7 females and 18 males. The respondents' age span is large, with the youngest is 27 , and the oldest is
61; most of them are at the age group of 30-40 (15 people out of 25). The questionnaire includes some questions about demographic information of the informants, 13 about general competences, 1 about general competence about foreign language skills, and 23 about subject specific competences. The information collected was entered into excel file. The employers' evaluation of the importance of the competences was tabulated against the employers' judgment on graduates' achievement of the competences.

\section{Findings}

The data in the below table 1 shows that general competences number $1,4,5,6,8,9$, and 13 were rated at high important but the level that graduates had achieved these competences were weak. These competences include: "no. 1: Ability to work collaboratively and effectively in diverse contexts", "no. 4. Ability to demonstrate responsibility and accountability towards the society and environment", "no. 5: Ability to communicate clearly and effectively", "no. 6: Ability to think critically, reflectively and innovatively", "no. 8. Ability to carry out lifelong learning and continuous professional development", "no.9: Demonstrate problem solving abilities", and "no. 13: Ability to apply knowledge into practice".

Importantly, these seven general competences are the graduate employability attributes in the above analysed literature, such as teamwork, problem solving, communication, interpersonal, critical thinking, and life-long learning skills. This result confirms the findings of other researches, e.g. $[25,29]$ that at graduation Vietnamese graduates did not have necessary attributes to satisfy the requirements of the real workplace. 
Table 1. The importance of the general competences for graduates, and level of achievements made by graduates

\begin{tabular}{|c|c|c|c|c|c|c|c|c|c|c|c|c|}
\hline \multirow[b]{2}{*}{$\mathbf{N}$} & \multirow[b]{2}{*}{$\begin{array}{l}\text { General } \\
\text { Competences }\end{array}$} & \multirow[b]{2}{*}{$\begin{array}{c}\text { Total } \\
\text { respondents }\end{array}$} & \multicolumn{5}{|c|}{ Importance for graduate } & \multicolumn{5}{|c|}{ Achievement by graduates } \\
\hline & & & None & Weak & $\begin{array}{c}\text { Conside } \\
\text { rable }\end{array}$ & Strong & $\begin{array}{c}\text { Missing } \\
\text { data }\end{array}$ & None & Weak & $\begin{array}{c}\text { Conside } \\
\text { rable }\end{array}$ & Strong & $\begin{array}{c}\begin{array}{c}\text { Missing } \\
\text { data }\end{array} \\
\end{array}$ \\
\hline 1 & $\begin{array}{l}\text { Ability to work } \\
\text { collaboratively } \\
\text { and effectively in } \\
\text { diverse contexts }\end{array}$ & 25 & $0 \%$ & $0 \%$ & $56 \%$ & $36 \%$ & 2 & $4 \%$ & $28 \%$ & $52 \%$ & $4 \%$ & 3 \\
\hline 2 & $\begin{array}{l}\text { Ability to use } \\
\text { information and } \\
\text { communication } \\
\text { technology } \\
\text { purposefully and } \\
\text { responsibly }\end{array}$ & 25 & $0 \%$ & $4 \%$ & $28 \%$ & $60 \%$ & 2 & $4 \%$ & $16 \%$ & $64 \%$ & $8 \%$ & 2 \\
\hline 3 & $\begin{array}{l}\text { Ability to uphold } \\
\text { professional, } \\
\text { moral and ethical } \\
\text { values }\end{array}$ & 25 & $0 \%$ & $0 \%$ & $8 \%$ & $84 \%$ & 2 & $0 \%$ & $4 \%$ & $68 \%$ & $12 \%$ & 4 \\
\hline 4 & $\begin{array}{l}\text { Ability to } \\
\text { demonstrate } \\
\text { responsibility and } \\
\text { accountability } \\
\text { towards the } \\
\text { society and } \\
\text { environment }\end{array}$ & 25 & $0 \%$ & $8 \%$ & $28 \%$ & $56 \%$ & 2 & $4 \%$ & $24 \%$ & $48 \%$ & $12 \%$ & 3 \\
\hline 5 & $\begin{array}{l}\text { Ability to } \\
\text { communicate } \\
\text { clearly and } \\
\text { effectively }\end{array}$ & 25 & $0 \%$ & $0 \%$ & $40 \%$ & $56 \%$ & 1 & $0 \%$ & $32 \%$ & $36 \%$ & $24 \%$ & 2 \\
\hline 6 & $\begin{array}{l}\text { Ability to think } \\
\text { critically, } \\
\text { reflectively and } \\
\text { innovatively }\end{array}$ & 25 & $0 \%$ & $0 \%$ & $16 \%$ & $72 \%$ & 3 & $12 \%$ & $24 \%$ & $36 \%$ & $16 \%$ & 3 \\
\hline 7 & $\begin{array}{l}\text { Ability to } \\
\text { understand, value, } \\
\text { and respect } \\
\text { diversity and } \\
\text { multiculturalism }\end{array}$ & 25 & $0 \%$ & $20 \%$ & $36 \%$ & $36 \%$ & 2 & $8 \%$ & $20 \%$ & $52 \%$ & $8 \%$ & 3 \\
\hline 8 & $\begin{array}{l}\text { Ability to carry } \\
\text { out lifelong } \\
\text { learning and } \\
\text { continuous } \\
\text { professional } \\
\text { development }\end{array}$ & 25 & $0 \%$ & $8 \%$ & $16 \%$ & $68 \%$ & 2 & $0 \%$ & $32 \%$ & $44 \%$ & $8 \%$ & 4 \\
\hline 9 & $\begin{array}{l}\text { Demonstrate } \\
\text { problem solving } \\
\text { abilities }\end{array}$ & 25 & $0 \%$ & $0 \%$ & $20 \%$ & $68 \%$ & 3 & $4 \%$ & $24 \%$ & $44 \%$ & $16 \%$ & 3 \\
\hline 10 & $\begin{array}{l}\text { Ability to } \\
\text { initiate, plan, } \\
\text { organise, } \\
\text { implement and } \\
\text { evaluate course of } \\
\text { actions }\end{array}$ & 25 & $0 \%$ & $8 \%$ & $48 \%$ & $36 \%$ & 2 & $4 \%$ & $32 \%$ & $44 \%$ & $8 \%$ & 3 \\
\hline 11 & $\begin{array}{l}\text { Ability to conduct } \\
\text { research }\end{array}$ & 25 & $0 \%$ & $12 \%$ & $44 \%$ & $36 \%$ & 2 & $8 \%$ & $32 \%$ & $32 \%$ & $20 \%$ & 2 \\
\hline 12 & $\begin{array}{l}\text { Ability to } \\
\text { demonstrate } \\
\text { leadership } \\
\text { attributes }\end{array}$ & 25 & $0 \%$ & $4 \%$ & $36 \%$ & $52 \%$ & 2 & $4 \%$ & $24 \%$ & $44 \%$ & $16 \%$ & 3 \\
\hline 13 & $\begin{array}{l}\text { Ability to apply } \\
\text { knowledge into } \\
\text { practice }\end{array}$ & 25 & $0 \%$ & $4 \%$ & $20 \%$ & $72 \%$ & 1 & $8 \%$ & $24 \%$ & $48 \%$ & $16 \%$ & 1 \\
\hline
\end{tabular}

When asked to prioritise 5 competences out of the general competences, no informant prioritised general competence number 4 "Ability to demonstrate responsibility and accountability towards the society and environment" despite their high rating of its importance (56\% rates it strong important, and $28 \%$ rate it considerable important). General competence number 7 "Ability to understand, value, and respect diversity and 
multiculturalism" and number 10 "Ability to initiate, plan, organise, implement and evaluate course of actions" receive $2 / 25(8 \%)$ votes each at low level priority (see table 2 ).

Table 2. Ranking the priority of general competences by Law employers

(Weight of ranking: $1^{\text {st }}$ priority $=5$ points $; 2^{\text {nd }}$ priority $=4$ points; $3^{\text {rd }}$ priority $=3$ points; $4^{\text {th }}$ priority $=2$ points; $5^{\text {th }}$ priority $=1$ point $)$

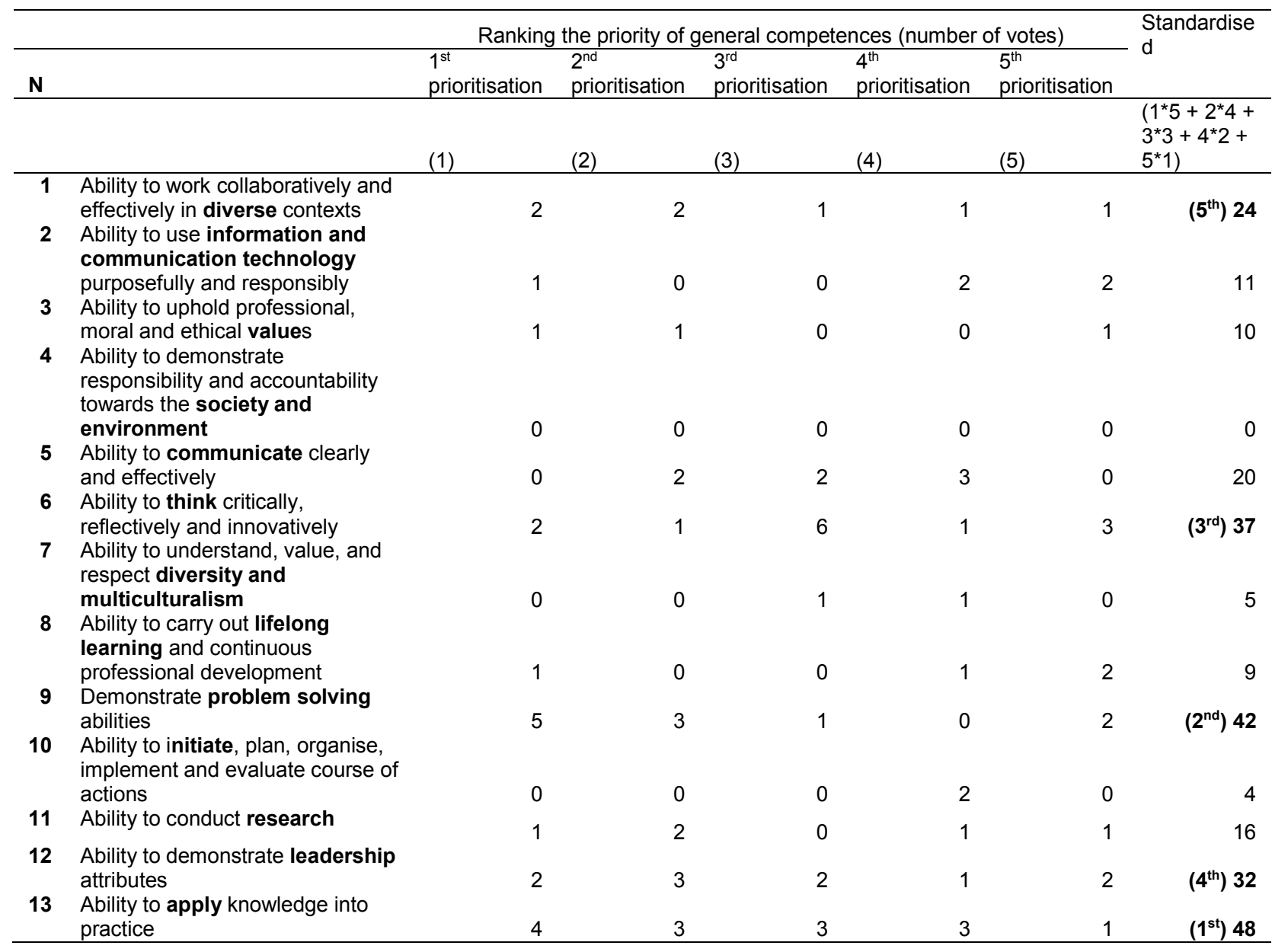

\section{Discussion and Conclusion}

Comparing Law employers' 5 prioritised competences (see Table 3 ) with the results of 5 prioritised competences in TUNING Asia South East project [30] for Teaching program, Civil Engineering program, and Medicine program, the results show that employers of VNU Law graduates share similar concern with employers of these three programs when they most concern for "Ability to apply knowledge into practice" (general competence 13). This general competence, ofcourse, is the final goal of all programs. These employers also share concern for "Ability to think critically, reflectively and innovatively" (general competence 6).

However, what distinguishes employers of VNU Law graduates from employers of other program is the concern for "Ability to work collaboratively and effectively in diverse contexts" (general competence 1) and "Ability to demonstrate leadership attributes" (general competence 12).

Although the priority of Law graduates' employers focused on general competences 1, $6,9,12,13$, their evaluation of Law graduates' 
achievements of these competences raises another concern for the education providers, academics and program managers. For all of these 5 general competences, about $28 \%$ to $32 \%$ of the employers evaluate that graduates having no competence and/or weak competence. These are the skills in the expected learning outcomes

Table 3. Compared ranking the priority of general competences of employers of different programs

\begin{tabular}{|c|c|c|c|c|c|}
\hline \multirow[b]{2}{*}{$\mathbf{N}$} & & \multicolumn{3}{|c|}{ TUNING - Asia South East project } & \multirow{2}{*}{$\begin{array}{l}\text { VNU Law } \\
\text { program }\end{array}$} \\
\hline & & Civil Engineering & Medicine & $\begin{array}{l}\text { Teacher } \\
\text { training }\end{array}$ & \\
\hline 1 & $\begin{array}{l}\text { Ability to work collaboratively and } \\
\text { effectively in diverse contexts }\end{array}$ & $2^{\text {nd }}$ & & $2^{\text {nd }}$ & $5^{\text {th }}$ \\
\hline 2 & $\begin{array}{l}\text { Ability to use information and } \\
\text { communication technology purposefully } \\
\text { and responsibly }\end{array}$ & & & & \\
\hline 3 & $\begin{array}{l}\text { Ability to uphold professional, moral and } \\
\text { ethical values }\end{array}$ & $3^{\text {rd }}$ & $1^{\text {st }}$ & $1^{\text {st }}$ & \\
\hline 4 & $\begin{array}{l}\text { Ability to demonstrate responsibility and } \\
\text { accountability towards the society and } \\
\text { environment }\end{array}$ & & & & \\
\hline 5 & $\begin{array}{l}\text { Ability to communicate clearly and } \\
\text { effectively }\end{array}$ & $4^{\text {th }}$ & & $5^{\text {th }}$ & \\
\hline 6 & $\begin{array}{l}\text { Ability to think critically, reflectively and } \\
\text { innovatively }\end{array}$ & & $3^{\text {rd }}$ & $3^{\text {rd }}$ & $3^{\text {rd }}$ \\
\hline 7 & $\begin{array}{l}\text { Ability to understand, value, and respect } \\
\text { diversity and multiculturalism }\end{array}$ & & & & \\
\hline 8 & $\begin{array}{l}\text { Ability to carry out lifelong learning and } \\
\text { continuous professional development }\end{array}$ & & $4^{\text {th }}$ & & \\
\hline 9 & Demonstrate problem solving abilities & & $5^{\text {th }}$ & & $2^{\text {nd }}$ \\
\hline 10 & $\begin{array}{l}\text { Ability to initiate, plan, organise, } \\
\text { implement and evaluate course of actions }\end{array}$ & $5^{\text {th }}$ & & & \\
\hline 11 & Ability to conduct research & & & & \\
\hline 12 & $\begin{array}{l}\text { Ability to demonstrate leadership } \\
\text { attributes }\end{array}$ & & & & $4^{\text {th }}$ \\
\hline 13 & Ability to apply knowledge into practice & $1^{\text {st }}$ & $2^{\text {nd }}$ & $4^{\text {th }}$ & $1^{\text {st }}$ \\
\hline
\end{tabular}

The preliminary result of the current research also confirms the finding from World Bank [29] study of employers' requirements, which showed that more than $80 \%$ of job applicants in Vietnam are lacking the skills the employers expected, specifically, job special skills and soft skills. The World Bank report [29] points out that the skills development system is "disconnected" between employers, students and universities, in which one side chooses, acts alone and does not interact with one another. Schools and universities provide programs and skills that do not adequately reflect the needs of the labor market. The low that the program promises to train their graduates, namely: teamwork, critical thinking, problem solving, interpersonal skills, and applying knowledge into practice. The task of the educators were not fulfilled as said in their statement of expected learning outcomes. rate of satisfaction to the university knowledge and skills against employers' requirements imply the gap between job market and education in the institutions [29].

Graduates have weak, even no such transferable skills, those that allow graduates to acquire the necessary skills, to satisfy the requirements of the new workplace, to transfer abstract cognitive skills [1], to work with others, to lead and to solve problems. These skills are needed before the graduates entered the work market as the empoyers expected them to practice these skills competently at work. Although these skills can be generated through 
work, the employers do emphasise their importance for univesrity graduates.

University teaching and learning process should be reviewed and revised in term of approaches, curriculum, and facilities to effectively develop these transferable skills for graduates. Other researchers suggested studentcentered learning approach, significant internship component should be integrated into the learning process [28] and university-industry link [25].

In today's society, the university-work transition has become increasingly challenging for graduates and employers. The traditional role of universities in producing knowledge has changed to give more focus on the demands of society. The fast development of information technology speeded up job nature changes; many new jobs are emerging while traditional ones are disappearing. In addition to discipline knowledge, graduates need to have transferable attributes such as team work skills, organisation skills, self-motivation, information technology skills; communication skills, initiative, creativity, problem solving skills, critical thinking, and leadership skills which help them to learn new skills, new knowledge to adap to new context.

As this is the preliminary result of the research, it is expected that the evaluation of employers of other VNU programs together with self-evaluation of graduates will give clear understanding of the market's expectation towards graduates from VNU. In future research, one quality component should be added to the research design that allows the researcher to interview and explore the perspectives at policy making level, among those who develop university programs. Their perspectives should have influenced significantly the way the programs were shaped and delivered.

\section{Acknowledgment}

This work is in a sense an outcome of research we started at Vietnam National University Hanoi (VNU), funded under research project number QG 18.58. We gratefully acknowledge enormous support from VNU Hanoi colleagues.

\section{Reference}

[1] Bennett, N., Dunne, E., Carré, C. (2000). Skills development in higher education and employment, (Buckingham; Philadelphia, PA:, Society for Research into Higher Education \& Open University Press).

[2] Barrie, S. (2006). Understanding What We Mean by the Generic Attributes of Graduates. Higher Education, 51(2), 215-241.

[3] Knight, P. T., \& Yorke, M. (2002). Employability through the curriculum. Tertiary Education \& Management, 8(4), 261-276.

[4] Bennett, R. (2002). Employers" Demands for Personal Transferable Skills in Graduates: a content analysis of 1000 job advertisements and an associated empirical study, Journal of Vocational Education and Training, 54:4, 457476, DOI: 10.1080/13636820200200209.

[5] Harvey, L. (2005). Embedding and integrating employability. New Directions for Institutional Research. (128), 13-26. doi:10.1002/ir.160.

[6] Sen, A. (2002). How to judge globalism. The American Prospect Online. Online resource. http://www.prospect.org/print/V13/1/sen-a.html. Accessed on 30 March 2013.

[7] Giddens, A. (1990). The consequences of modernity. Stanford, Calif: $\quad$ Stanford University Press.

[8] Marginson, S., \& van der Wende, M. (2009). The new global landscape of nations and institutions. Organization for Economic Cooperation and Development Higher education to 2030, 2(Globalization), 17-62.

[9] Altbach, P. G. (2010). The realities of mass higher education in a globalized world. In D. B. Johnstone, M. d'Ambrosio \& P. J. Yakoboski (Eds.), Higher education in a global society (pp. 25-41). Cheltenham: Edward Elgar Publishing.

[10] Marginson, S. (2008). Global field and global imagining: Bourdieu and worldwide higher education. British Journal of Sociology of Education, 29(3), 303 - 315.

[11] Douglass, J., Thomson, G., \& Zhao, C.-M. (2012). The learning outcomes race: the value of selfreported gains in large research universities. Higher Education, 64(3), 317-335. 
[12] Eraut, M. (2004). Transfer of knowledge between education and workplace settings. In H. Rainbird, A. Fuller \& A. Munro (Eds.), Workplace learning in context (pp. 201-221). London ; New York: Routledge.

[13] Hernández-March, J., Martín del Peso, M., \& Leguey, S. (2009). Graduates' Skills and Higher Education: The employers' perspective. Tertiary Education and Management, 15(1), 1-16. http://dx.doi.org/10.1080/13583880802699978

[14] Harvey, L., Moon, S., Geall, V., \& Bower, R. (1997). Graduates' Work: Organisational Change and Students' Attributes. Centre for Research into Quality, 90 Aldridge Road, Perry Barr, Birmingham B42 2TP, England, United Kingdom (5 British pounds).

[15] Holden, R., \& Jameson, S. (2002). Employing graduates in SMEs: towards a research agenda. Journal of Small Business and Enterprise Development, 9(3), 271-284.

[16] Fallows, S., \& Steven, C. (2013). Integrating key skills in higher education: Employability, transferable skills and learning for life. Routledge.

[17] Haigh, M. J., \& Kilmartin, M. P. (1999). Student perceptions of the development of personal transferable skills. Journal of Geography in Higher Education, 23(2), 195-206. Retrieved from

https://search.proquest.com/docview/214735353? accountid $=39811$

[18] Lowden, K., Hall, S., Elliot, D., \& Lewin, J. (2011). Employers' perceptions of the employability skills of new graduates. London: Edge Foundation.

[19] Suleman, F. (2016). Employability skills of higher education graduates: Little consensus on a muchdiscussed subject. Procedia-Social and Behavioral Sciences, 228, 169-174. Paper presented in the Proceedings of 2nd International Conference on Higher Education Advances, HEAd'16, 21-23 June 2016, València, Spain.

[20] Little, B. (2006). Employability and work-based learning. York: Higher Education Academy, 2006.
[21] Stephenson, J. (2013). "The Concept of Capability and Its Importance in Higher Education," in Capability and quality in higher educationJ. Stephenson and M. Yorke, Eds. Routledge, pp. 1-13.

[22] Yorke, M., \& Harvey, L. (2005). Graduate Attributes and Their Development. In R. A. Voorhees \& L. Harvey (Eds.), Workforce development and higher education: a strategic role for institutional research (pp. 41-58). San Francisco: Jossey-Bass.

[23] Maclean, R., \& Ordonez, V. (2007). Work, skills development for employability and education for sustainable development. Educational Research for Policy and Practice, 6(2), 123-140.

[24] De Weert, E. (2007). Graduate Employment in Europe: The Employers' Perspective. In U. Teichler (Ed.), Careers of University Graduates (Vol. 17, pp. 225-246): Springer Netherlands.

[25] Tran Quang Trung, \& Swierczek, F. W. (2009). Skills development in higher education in Vietnam. Asia Pacific Business Review, 15(4), 565-586.

[26] Nguyen Thi Thanh Hong. (2008). "Factors influencing the self-study quality for education theory subject of the students at Universities of Education". Vietnamese Education Review, vol. 182, no.2, pp. 22-24.

[27] World Bank. (2008). Vietnam - Higher education and skills for growth. Washington, DC: World Bank, 2008.

[28] Mai Thi Quynh Lan (2017). The "person-inbetween" role of young graduates at INGOs in Vietnam. Journal of Teaching and Learning for Graduate Employability, 8(1), 137-151. http://dx.doi.org/10.21153/jtlge2017vol8no1 art626

[29] World Bank. (2013). Vietnam development report: preparing the work force for a modern market economy: Main report. Washington DC; World Bank, vol. 2.

[30] TUNING Asia South East project (2017). Second General Meeting. Kuala Lumpur, 15-19 October 2017. Tuning Academy. Retrieved from http://tuningasia-southeast.org/wpcontent/uploads/2017/11/TA-SE-2GMBooklet.pdf 


\title{
Khoảng cách kỹ năng của sinh viên tốt nghiệp từ đánh giá của nhà tuyển dụng: Nghiên cứu trường hợp của sinh viên tốt nghiệp Đại học Quốc gia Hà Nội
}

\author{
Mai Thị Quỳnh Lan \\ Viện Đảm bảo Chất luợng Giáo duc, Đại học Quốc gia Hà Nội, \\ 144 Xuân Thuý, Cầu Giấy, Hà Nội, Việt Nam
}

Tóm tắt: Với toàn cầu hóa, quá trình chuyển tiếp từ trường đại học sang công việc thực tế trở nên ngày càng khó khăn cho sinh viên tốt nghiệp và người sử dụng lao động. Trong bối cảnh mới, nhiệm vụ của trường đại học đã thay đổi và kiến thức không còn được coi là số ít [1]. Vai trò truyền thống của các trường đại học trong việc tạo ra tri thức đã thay đổi để tập trung hơn vào nhu cầu của xã hội. "Kiến thức được mã hóa" thu được từ việc giảng dạy giáo khoa trong các trường đại học có thể mâu thuẫn với kiến thức "không chính thức và ngầm" cần thiết tại nơi làm việc. Sự phát triển của công nghệ thông tin làm cho bản chất của công việc thay đổi rất nhanh; sinh viên tốt nghiệp cần có các phẩm chất giúp họ không chỉ làm công việc tương ứng với ngành học của họ, mà còn có thể học các kỹ năng mới và kiến thức mới. Bài viểt này trình bày các kết quả ban đầu của một cuộc khảo sát qua phiếu hỏi đối với 25 nhà tuyển dụng sinh viên Khoa Luật - ĐHQGHN để khám phá đánh giá của người sử dụng lao động của sinh viên tốt nghiệp từ Đại học Quốc gia Hà Nội. Áp dụng các lý thuyết về các phẩm chất của sinh viên tốt nghiệp đại học [2], khả năng có thể làm việc [3] và các kỹ năng chuyển tiếp của sinh viên tốt nghiệp đại học $[4,5]$, cuộc khảo sát tìm hiểu sự cách biệt giữa việc học ở trường đại học của sinh viên tốt nghiệp so với các yều cầu của thị trường lao động. Bài viết này lập luận rằng có sự cách biệt đáng kể giữa kiến thức và kỹ năng của trường đại học và bản chất của công việc. Sinh viên tốt nghiệp thiếu các kỹ năng có thể chuyển đổi là những kỹ năng cho phép họ học hỏi các kỹ năng cần thiết để đáp ứng các yêu cầu của môi trường làm việc hiện đại, để chuyển đổi các năng lực nhận thức. Những kỹ năng này là cần thiết trước khi sinh viên tốt nghiệp bước vào thị trường lao động, nơi mà các nhà tuyển dụng đòi hỏi sinh viên tốt nghiệp phải thực hành thành thạo các kỹ năng này trong công việc. Mặc dù những kỹ năng này có thể được tạo ra thông qua công việc, các nhà tuyển dụng vẫn nhấn mạnh tầm quan trọng của các kỹ năng này đối với sinh viên tốt nghiệp đại học. Do đó, quá trình dạy và học đại học cần được xem xét và sửa đổi (nếu cần thiết) để phát triển các kỹ năng có thể chuyển đổi này ngay trong thời gian học tại trường đại học.

Tù khóa: Phẩm chất của sinh viên tốt nghiệp đại học, khả năng có thể làm việc, Việt Nam, năng lực chung, kỹ năng có thể chuyển đổi. 